Семененко В. М., к.т.н, с.н.с. (ORCID 0000-0001-5774-0868);

Сурков О. О., к.військ.н. (ORCID 0000-0002-8189-0484);

Наливайко А. Д., к.т.н., доцент (ORCID 0000-0002-0675-9603)

Центр воєнно-стратегічних досліджень Національного університету оборони України імені Івана Черняховського, Київ

\title{
Аналіз організації стратегічного (оборонного) планування в збройних силах Литовської Республіки
}

Резюме. Відповідно до Закону України “Про національну безпеку України” у рамках виконання завдань стратегічної цілі 2 Стратегічного оборонного бюлетеня України проаналізовано досвід стратегічного (оборонного) планування та розвитку національної системи оборони Литовської Республіки.

Ключові слова: стратегічне планування; оборонне планування; спроможності; типовий сценарій планування.

Постановка проблеми. 22 листопада 2018 року Верховна Рада України у першому читанні затвердила президентський законопроект "Про внесення змін до Конституції України щодо стратегічного курсу держави на набуття повноправного членства України в Свропейському Союзі та в Організації Північноатлантичного договору", (№ 9037).

У зв'язку 3 цим досвід Литовської республіки, донещодавна пострадянської республіки, а наразі повноправного члена політико-економічного та оборонного європейського співтовариства, у тому числі і стосовно організаціі стратегічного (оборонного) планування, $€$ корисним для нашої країни.

Після розвалу Радянського Союзу у вересні 1991 року Литовська республіка проголосила незалежність, 32002 року вона $є$ членом Організації Північноатлантичного договору, з 2004 - Європейського Союзу. Литовська Республіка запровадила оборонне планування на основі спроможностей у 2010 році. 3 початком агресії РФ проти України планування на основі спроможностей у Литві, як і в Альянсі загалом, здійснюється 3 урахуванням загроз і потребує синхронізації його циклів, завдань та заходів із процесом оборонного планування НАТО (NDPP). Для налагодження наявної системи, яка вже довела свою ефективність, знадобилося близько п'яти років [3].

Аналіз останніх досліджень і публікацій. Існуючий пакет основних документів стратегічного оборонного планування Литовської Республіки має розподіл за рівнями та горизонтами планування [4-7].
У рамках довгострокового планування (10 i більше років) на стратегічному рівні розробляються: Стратегія національної безпеки (NSS-2017), Воєнна стратегія (NMS-2016), Візія Збройних Сил (Armed Forces Vision-2025), Державна оборонна концепція (State Armed Defence Concept 2015); на виконавчому рівні в Міністерстві національної оборони (МНО) Біла книга з оборонної політики Литви (White Paper: Lithuanian Defence Policy 2017), Програма розвитку національної системи оборони (National Defence Development Programme), Ресурсний план (10Y Recource Plan).

У рамках середньострокового планування (4-9 років) на політико-стратегічному рівні ухвалюється Міжпартійна угода (Political Parties' Agreement) та розробляється Урядова програма (Government Programme); на виконавчому рівні (МНО) - Військовополітичні вказівки Міністра національної оборони (Guidance of the Minister).

У рамках короткострокового планування у МНО спільно зі Штабом оборони розробляється Стратегічний план дій на 3 роки (1+2Y Strategic Activity Plan), який містить цілі, завдання i заходи у рамках імплементації довго- та середньострокових програм і має ресурсну складову.

Метою статті $€$ аналіз організації стратегічного (оборонного) планування в збройних силах Литовської Республіки для врахування цього досвіду під час проведення оборонної реформи сектору безпеки і оборони України.

Викладення основного матеріалу. Цикл оборонного планування в Литовській республіці охоплює період 4 роки, протягом якого проводиться розроблення (перегляд) 
довгострокових і середньострокових стратегічних документів, концепцій, планів i програм у сфері оборони; здійснюється огляд спроможностей i розроблення (коригування) планів їх розвитку 3 урахуванням уточнення відповідних сценаріїв планування та ресурсних можливостей.

Загальну схему процесу оборонного планування та розподіл відповідальності за відпрацювання його окремих елементів наведено на рис. 1.
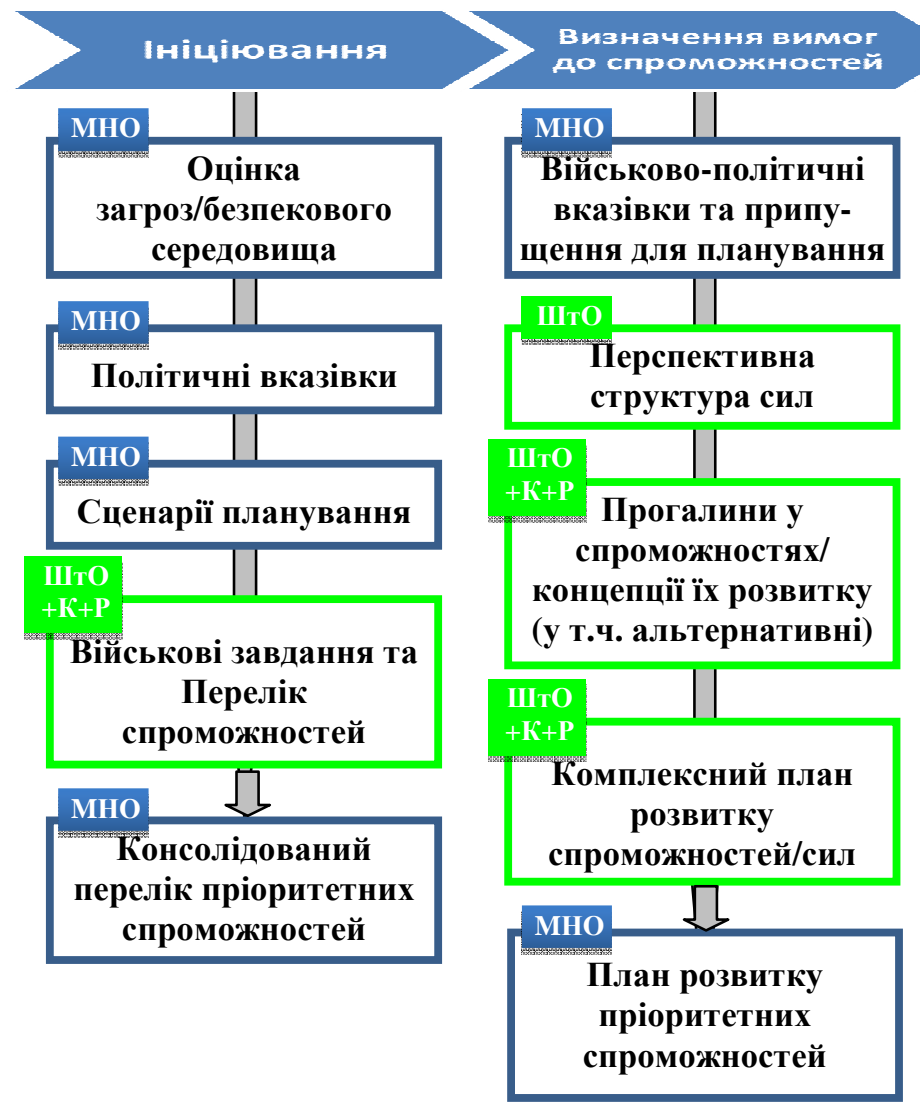

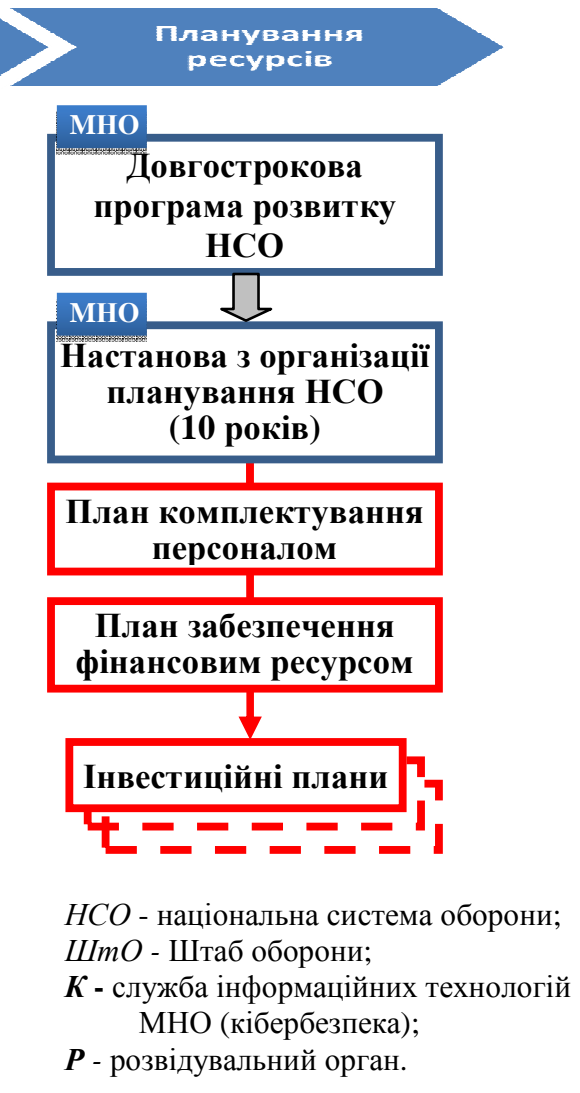

Рис. 1. Процес оборонного планування у Міністерстві національної оборони та Штабі оборони збройних сил Литовської Республіки

У рамках планування розвитку національної системи оборони:

МНО Литовської Республіки відповідає за формування військово-політичних вказівок щодо планування, доведення основних макроекономічних показників, визначення пріоритетних проектів iз розвитку спроможностей, відповідно до пропозицій Штабу оборони, та здійснює загальну консолідацію планів їх розвитку у Програму розвитку національної системи оборони;

Штаб оборони відповідає за розроблення Державної оборонної концепції, (на основі сценаріїв, які розробляються спільно 3 МНО); аналіз наявних спроможностей i визначення прогалин; розроблення довгострокових планів розвитку спроможностей, які $є$ основою для розроблення Програми розвитку національної системи оборони; планування сил (формування необхідних організаційноштатних структур і табелів до штатів (Tables of Organization and Equipment), 3 обгрунтуванням потреб у ресурсах 3 урахуванням життєвого циклу спроможностей (пропозиції до Ресурсного плану).

Загальну схему розмежування повноважень наведено на рис. 2.

Наразі у МНО та Штабі оборони розроблено 11 сценаріїв, які використовуються у стратегічному (оборонному) плануванні та охоплюють ситуації, які передбачають різні масштаби залучення ЗС Литовської Республіки. Існує три категорії споріднених сценаріїв, а саме: категорія "Мирний час" включає сценарії "Ліквідація наслідків надзвичайної ситуації природного або техногенного характеру”, "Пошуково-рятувальна операція" та інші; категорія "Воєнна криза" включає сценарії "Надання підтримки країною, що приймає" (HNS), “Операція НАTO з реагування на кризу поза межами території Литви” (CRO) та інші; категорія "Воєнний стан" включає сценарії "Операція НАТО за статтею 5 на території Литви”, “Операція НАТО за статтею 5 поза межами Литви” та інші. 


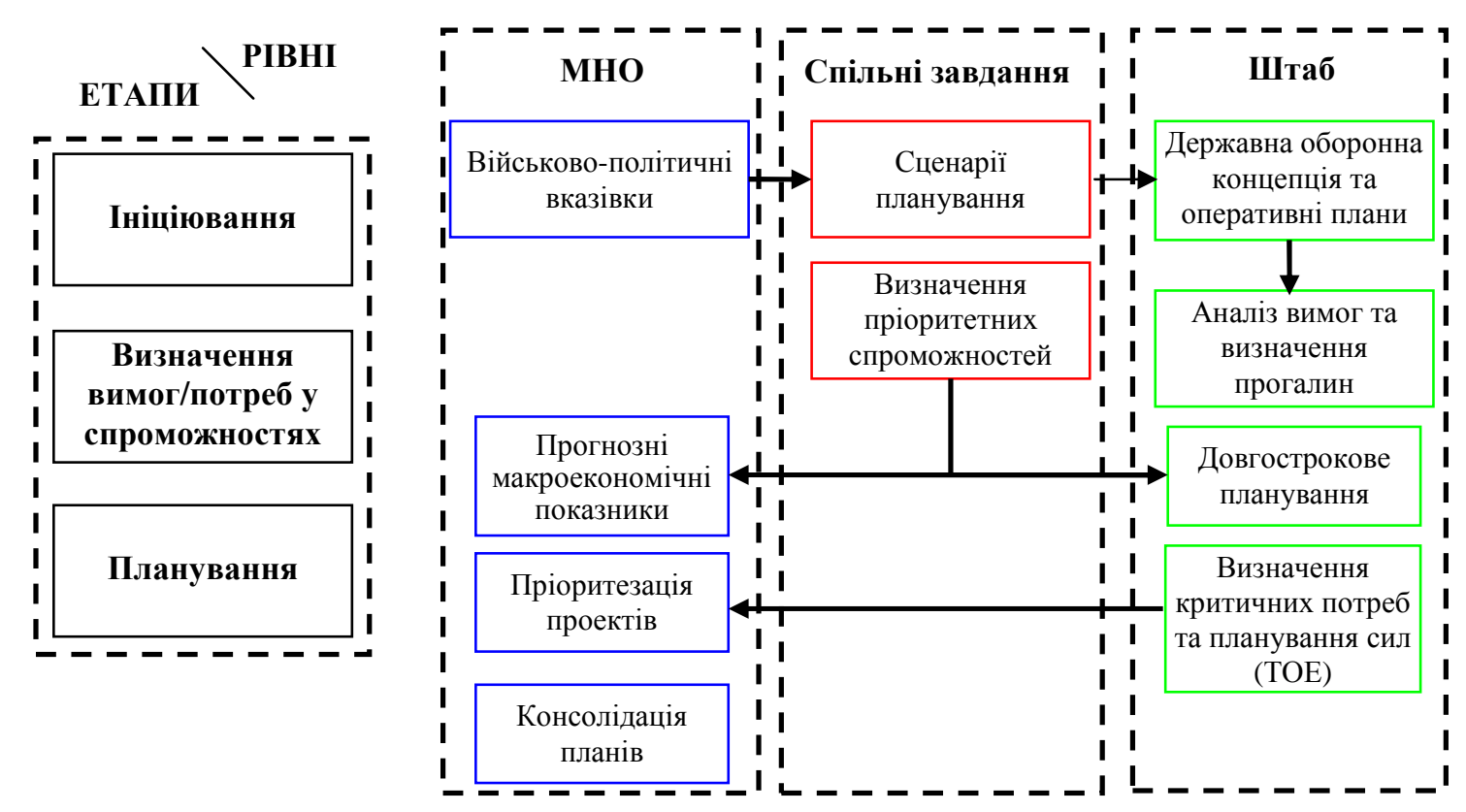

Рис. 2. Розподіл функцій планування розвитку

Опис типового сценарію наведено у зведеній табл. 1.

Таблиця 1

\section{Структура та основні параметри типового сценарію планування}

\begin{tabular}{|c|c|c|}
\hline \multicolumn{3}{|r|}{ Загальні характеристики сценарію } \\
\hline Опис сценарію & \multicolumn{2}{|r|}{$\begin{array}{l}\text { Детальний опис сценарію: суб’єкт і предмет, основні заходи, оцінювання загального } \\
\text { геополітичного, економічного, соціального та безпекового середовища (ситуації) в } \\
\text { регіоні. } \\
\text { Інформація щодо динамічних характеристик сценарію (його розвиток, політичні, } \\
\text { економічні, соцілальні, військові та технологічні фактори/умови, що впливають на } \\
\text { розроблення сценарію), етапи сценарію }\end{array}$} \\
\hline Джерела загрози & \multicolumn{2}{|r|}{$\begin{array}{l}\text { Визначення суб'єктів (особи, організації, явища/процеси), що становлять загрозу, а } \\
\text { також опис їх можливих дій і заходів }\end{array}$} \\
\hline $\begin{array}{l}\text { Наслідки у разі ігнорування } \\
\text { (можлива очікувана шкода) }\end{array}$ & \multicolumn{2}{|r|}{$\begin{array}{lcccc}\text { Можливі зміни безпекової ситуації, } & \text { потенційна } & \text { шкода, } & \text { наслідки } \\
\text { бездіяльності/відсутності реакції на загрозу } & & & \\
\end{array}$} \\
\hline $\begin{array}{l}\text { Політико-правові } \\
\text { передумови, припущення та } \\
\text { обмеження }\end{array}$ & \multicolumn{2}{|r|}{$\begin{array}{l}\text { Політико-правові передумови та обмеження, що впливатимуть або можуть вплинути } \\
\text { на характеристики сценарію i застосування спроможностей } \\
\text { застосування зброї масового ураження тощо) }\end{array}$} \\
\hline Зовнішні внески & \multicolumn{2}{|r|}{ Оцінювання допомоги з боку союзників, партнерів та міжнародних організацій } \\
\hline $\begin{array}{l}\text { Мета та очікуємий } \\
\text { результат місії }\end{array}$ & \multicolumn{2}{|r|}{$\begin{array}{l}\text { Бажаний у рамках сценарію результат у разі застосування військових } \\
\text { спроможностей }\end{array}$} \\
\hline \multicolumn{3}{|r|}{ Спеціальні характеристики сценарію } \\
\hline \multicolumn{2}{|l|}{ Інтенсивність операції } & Низька/середня/висока \\
\hline \multicolumn{2}{|l|}{ Тривалість місії } & $\begin{array}{l}\text { Часові показники виконання місії: } \\
\text { несподівано (негайно) - до } 7 \text { днів; } \\
\text { дуже швидко - від } 7 \text { до } 30 \text { днів; } \\
\text { швидко - від } 30 \text { до } 90 \text { днів; } \\
\text { середньої тривалості - від } 90 \text { до } 180 \text { днів; } \\
\text { довго - понад } 2 \text { роки }\end{array}$ \\
\hline \multicolumn{2}{|c|}{$\begin{array}{l}\text { Можливі напрями передислокації } \\
\text { (відстань від об'єкта) }\end{array}$} & $\begin{array}{l}\text { Відстань від столиці до зони проведення операції - залежить від місия ї̈ } \\
\text { проведення, радіус вимірюється в кілометрах. Визначається географічний } \\
\text { район проведення операції (наприклад, Європа, Литва, Африка тощь) }\end{array}$ \\
\hline \multicolumn{3}{|r|}{ Опис загрози } \\
\hline \multicolumn{2}{|l|}{ Середовище } & дружнє/нейтральне/вороже - інші характеристики \\
\hline \multicolumn{2}{|l|}{ Загальна загроза } & $\begin{array}{l}\text { Опис імовірного масштабу і характеру загрози, оцінювання внутрішніх } \\
\text { зовнішніх чинників, прогноз нанесення ймовірної шкоди військовому } \\
\text { потенциіалу: } \\
\text { значна (-75\% військового потенціалу); } \\
\text { середня (-50\% військового потенціалу); } \\
\text { низька (-25\% військового потенціалу) }\end{array}$ \\
\hline
\end{tabular}




\begin{tabular}{|c|c|}
\hline $\begin{array}{l}\text { Ключові характеристики } \\
\text { противника (військова стратегія, } \\
\text { спроможності, потенційні дії) }\end{array}$ & 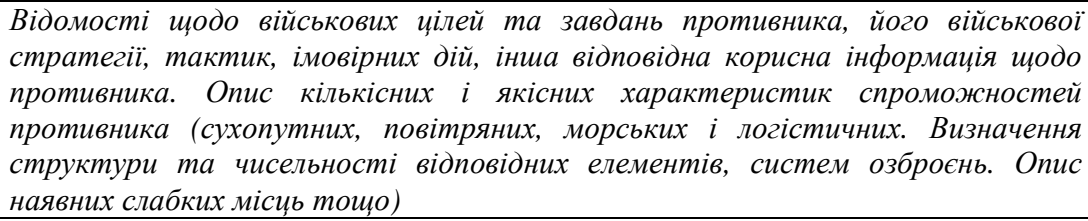 \\
\hline \multicolumn{2}{|r|}{ Стійкість (витривалість) } \\
\hline $\begin{array}{l}\text { Можливість надання підтримки } \\
\text { (логістичної) з боку країни, що } \\
\text { приймає }\end{array}$ & $\begin{array}{l}\text { Можливість надання логістичної підтримки краӥною, що приймає (у т.ч. } \\
\text { спроможності шодо прийняття вантажів, їх тимчасового зберігання й } \\
\text { перемішення до району проведення операції, перевезення безпосередньо в } \\
\text { районі проведення операції, зберігання та захисту). } \\
\text { Якісна характеристика можливості (потенціалу краӥни) надання підтримки } \\
\text { за відповідними критеріями, зокрема: } \\
\text { можливість відсутня; } \\
\text { низька - < } 25 \% \text {; } \\
\text { середня - від } 25 \text { до } 50 \% \text {; } \\
\text { значна - від } 50 \text { до } 75 \% \text {; } \\
\text { висока - від } 75 \text { до } 100 \%\end{array}$ \\
\hline $\begin{array}{l}\text { Умови для прийняття наземних } \\
\text { підрозділів }\end{array}$ & $\begin{array}{l}\text { Оцінювання можливостей щодо розташування особового складу та наявності } \\
\text { складських приміщень за такими категоріями: } \\
\text { відсутні можливості; } \\
\text { низькі можливості; } \\
\text { розвинуті можливості }\end{array}$ \\
\hline Характеристики авіаційних баз & $\begin{array}{l}\text { Оцінювання можливостей з надання послуг авіаційних баз за такими } \\
\text { категоріями: } \\
\text { наявні/відустні/відповідають потребі/не відповідають потребі/розмір } i \\
\text { характеристики авіабази/спроможності шуодо надання послуг з управління } \\
\text { повітряним рухом }\end{array}$ \\
\hline Морські порти & $\begin{array}{l}\text { Оцінювання стану розвитку інфраструктури морських портів за такими } \\
\text { категоріями: } \\
\text { наявна/відустня/слабо розвинута/добре розвинута/розмір } і \text { характеристики } \\
\text { порту/ характер узбережжя тощя }\end{array}$ \\
\hline Система зв’язку та комунікацій & $\begin{array}{l}\text { Можливість використання наявних спроможностей системи зв'язку та } \\
\text { інформації безпосередньо в районі проведення операџї або можливість } \\
\text { створення нової системи. Визначається за такими категоріями: } \\
\text { відсутня/наявна }\end{array}$ \\
\hline Угоди щодо транзиту & $\begin{array}{l}\text { Наявність дозволу (угоди) на використання наземного/повітряного/морського } \\
\text { простору; положення угоди або домовленостей }\end{array}$ \\
\hline \multicolumn{2}{|c|}{ Фізичні характеристики та технічні спроможності району проведення операції } \\
\hline Розмір зони проведення операції & 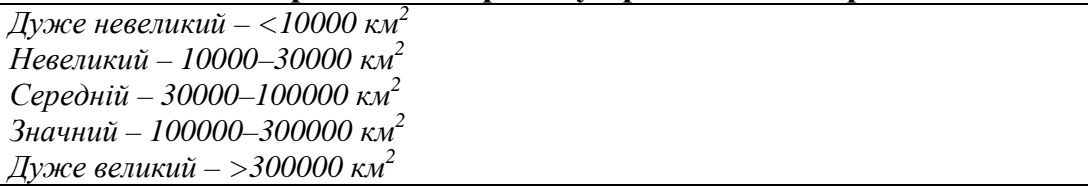 \\
\hline $\begin{array}{l}\text { Доступність району проведення } \\
\text { операції }\end{array}$ & $\begin{array}{l}\text { Оиінювання можливості доступу до району проведення операції та } \\
\text { пересування в його межах із використанням наземного, повітряного та } \\
\text { морського транспорту }\end{array}$ \\
\hline Наземні шляхи сполучення & $\begin{array}{l}\text { Можливості (обмеження) шуодо використання наземних шляхів сполучення в } \\
\text { районі проведення операції. Фізичні характеристики шляхів сполучення } \\
\text { (наприклад, характеристики доріг за такими категоріями: обмежений доступ } \\
\text { до використання доріг, обумовлений сезонними особливостямиобмежена } \\
\text { дорожня мережа/відсутність доріг тощуо) }\end{array}$ \\
\hline Повітряні шляхи сполучення & $\begin{array}{l}\text { Можливості (обмеження) щзодо використання повітряних шляхів сполучення в } \\
\text { районі проведення операції. Визначається за такими категоріями: } \\
\text { наявна/відсутня }\end{array}$ \\
\hline Морські шляхи сполучення & $\begin{array}{l}\text { Можливості (обмеження) щиодо використання морських иляхів сполучення в } \\
\text { районі проведення операцї. Визначається за наступними категоріями: } \\
\text { наявна/відсутня. }\end{array}$ \\
\hline Інтенсивність руху & Очінювання навантаження иляхів сполучення (низьке/середнє/високе) \\
\hline \multicolumn{2}{|r|}{ Географічні відомості щодо району проведення операцій } \\
\hline Демографічні відомості & Населення, найбільші міста в районі проведення операчії \\
\hline Рельєф & $\begin{array}{l}\text { Гори/схили/рівнини/низовини/джунглі/пустелі/ліси/поля; міста/селища; } \\
\text { озера/річки/інші внутрішні водоймищуа }\end{array}$ \\
\hline Глибина узбережжя & Інформачія шеодо середньої глибини узбережжя, перепадів глибин, дна \\
\hline Протяжність узбережжя & $\begin{array}{l}\text { Визначається за такими категоріями: коротка - <500 км; середня - від } 500 \text { до } \\
1000 \text { км; велика ->1000 км або - не застосовується. }\end{array}$ \\
\hline Характер узбережжя & Пішеане/скелясте; схил узбережжя; повені (так/ні) або їх масштаб. \\
\hline Клімат & Середні кліматичні показники за тривалий проміжок часу \\
\hline
\end{tabular}


Водночас, організація Стратегічного (оборонного) планування на рівні органу стратегічного військового управління (Штабу оборони) має свої особливості щодо основних процесів і складових планування розвитку спроможностей збройних сил; порядку взаємодії з МНО Литовської Республіки на всіх етапах стратегічного (оборонного) планування i ключових структурних підрозділів, які безпосередньо залучені до здійснення планування.

Для реалізації цих функцій у Штабі оборони створено окремі структурні підрозділи: департамент J-53 (стратегічне планування застосування збройних сил у майбутніх операціях, розроблення оперативних концепцій) i департамент J-55 (стратегічне планування розвитку ЗС Литовської Республіки, визначення вимог до спроможностей, ведення каталогу спроможностей і розроблення довгострокових планів i програм їx розвитку, організація військового співробітництва в інтересах розвитку спроможностей 3 С).

Ця система дає змогу здійснювати адаптивне планування розвитку збройних сил країни, враховувати перспективні (довгострокові) потреби у спроможностях для забезпечення національної оборони та виконання зобов'язань у системі колективної безпеки НАТО.

Наразі Державною оборонною концепцією Литовської Республіки визначено чотири ключові напрями зосередження зусиль, а саме:

розвиток національних сил швидкого реагування, здатних забезпечити швидке розгортання i виконання першочергових завдань оборони у визначених районах до розгортання основних сил (у т.ч. союзників);

впровадження нових підходів до організації територіальної оборони, збільшення чисельності сухопутної компоненти збройних сил;

забезпечення узгодженості між складом збройних сил мирного та воєнного часу;

забезпечення функціонування змішаної системи комплектування (професійні військовослужбовці, строкова служба, волонтери, служба у військовому резерві).

У Штабі оборони розроблено логічноієрархічну структуру спроможностей (каталог), яка містить шість функціональних груп:

"C2" - система управління; розвідка;
"Combat" - бойові та спеціальні спроможності;

"Force Protection" - захист військ (сил);

"Logistics" - логістика;

"Institutional" _ - інституційні спроможності.

Каталог $\epsilon$ основою для формування планів розвитку окремих спроможностей. $3 \mathrm{i}$ свого боку зазначені плани надають вихідні дані для дев'яти відомчих довгострокових програм (CB, ПС, ВМС, ССпО, Логістика, Підготовка персоналу, Поточні операції, Централізовані послуги і закупівлі, МНО). Відомчі програми використовуються для розроблення документів короткострокового планування, зокрема бюджетного планування (1-2 роки).

Плани розвитку спроможностей розраховані на довгострокову перспективу та містять цілі, завдання i заходи щодо їх досягнення за всіма базовими компонентами спроможностей (DOTMLPF-1), із розподілом за роками та етапами (від набуття початкових до досягнення повних спроможностей).

Зважаючи на те, що Литва $€$ країноючленом Альянсу, значний вплив у визначенні пріоритетів розвитку національних військових спроможностей мають регулярні оцінки та цільові вимоги щодо спроможностей з боку HATO (NATO Assessments and Capability Target Requirements).

Висновок. У статті проведено аналіз і розглянуто особливості організації стратегічного (оборонного) планування в Литовській Республіці. Зазначено, що основоположні принципи та методологічні підходи до організації (впровадження) стратегічного (оборонного) планування в Україні й у Литовській Республіці є подібними та відповідають сучасним практикам провідних держав-членів НАТО.

У подальших дослідженнях доцільно імплементувати набутий досвід стратегічного (оборонного) планування в Литовській Республіці під час огляду спроможностей Збройних Сил України. Продовжити вивчення та використання практичного досвіду МНО i Штабу оборони ЗС Литовської Республіки щодо організації та виконання усіх етапів циклу стратегічного (оборонного) планування, зокрема у контексті підготовки і проведення оборонного огляду у Міністерстві оборони та Збройних Силах України.

\section{СПИСОК ВИКОРИСТАНОЇ ЛІТЕРАТУРИ}

1. Закон України "Про національну безпеку України”, 21 червня 2018 року, № 2469-VIII. 
2. Стратегічний оборонний бюлетень України, затверджений Указом Президента України № 240/2016 від 6 червня 2016 року.

3. Звіт за результатами візиту делегації Міністерства оборони України до Литовської республіки (26-27.09.2018, м. Вільнюс). Реєстр. № 14934/3/1 від 05.10.2018 (Міністерство оборони України).

4. White paper. Lithuanian Defence Policy 2017. Vilnius: Ministry of National Defence of the Republic of Lithuania, 2017. - 59 p.
5. National Threat Assessment 2018. - Vilnius: Ministry of National Defence Republic of Lithuania, 2018. - 59 p.

6. Lithuanian Defence System: Facts and Trends. Vilnius: Ministry of National Defence of the Republic of Lithuania, 2017. - 17 p.

7. The World 2030. Updated and expanded edition. Vilnius: Ministry of National Defence of the Republic of Lithuania, 2013. - 93 p.

Стаття надійшла до редакційної колегії 23.11.2018

Семененко В. М., к.т.н, с.н.с.;

Сурков О. А., к.воен.н.;

Наливайко А. Д., к.т.н., доцент

Центр военно-стратегических исследований Национального университета обороны Украины имени Ивана Черняховского, Киев

\section{Анализ организации стратегического (оборонного) планирования в вооруженных силах Литовской Республики}

Резюме. В соответствии с Законом Украины “Про национальную безопасность Украины” в рамках выполнения задач стратегической цели 2 Стратегического оборонного бюллетеня Украины, проанализирован опыт стратегического (оборонного) планирования и развития национальной системы обороны Литовской Республики.

Ключевые слова: стратегическое планирование; оборонное планирование; возможности; типичный сценарий планирования.

\section{Semenenko, PhD (Technical), senior researcher;}

O. Surkov, PhD (Military);

A. Nalivayko, PhD (Technical), associate professor

Center for Military and Strategic Studies of the National Defence University of Ukraine named after Ivan Cherniakhovskyi, Kyiv

Analysis of organization of strategic (defense) planning in the Armed Forces of the

\section{Republic of Lithuania}

Resume. The experience of strategic (defense) planning and development of the national defense system of the Republic of Lithuania has been analyzed in accordance with the Law of Ukraine "On National Security of Ukraine", within the framework of the fulfillment of the objectives of Strategic Goal 2 of the Strategic Defense Bulletin of Ukraine.

Keywords: strategic planning; defense planning; capability; typical scenario planning. 